\title{
STUDY OF PULMONARY FUNCTION TESTS IN INDIVIDUALS ENGAGED IN TRADITIONAL INDIAN EXERCISES IN AKHADA
}

\author{
Amarjeet Singh Chhabra, Priti Taneja \\ 1. Assistant Professor. Department of Physiology, MGM Medical College, Indore. \\ 2. Ret. Professor \& Head. Department of Physiology, MGM Medical College, Indore.
}

\section{CORRESPONDING AUTHOR}

Amarjeet Singh Chhabra, 155B Amitesh Nagar,

Sc No 59,Near Choithram Mandi, Indore-452014,

E-mail: amarjeet_singh_c@rediffmail.com

Ph: 00919893282450

\begin{abstract}
BACKGROUND: It is well known that exercise has a significant effect on respiratory functions. As reports on effects of exercise in Akhada Pahalwan on Pulmonary Functions are not available; the present study was carried out in young male adults of Eighteen to Thirty years of age group to assess their Pulmonary Functions. METHODS: Subjects were divided into two groups (study group and control group). Subjects of Study group (Akhada Pahalwan, $n=37$ ) were engaged in exercise in Akhada for at least two years. Control group ( $n=$ 30) was of medical students not engaged in any regular exercise. Lung volumes were recorded by Pulmonary Function test machine and analysed statistically. RESULTS: It was found that akhada pahalwan (Study group) had larger lung volume as compared to control group.
\end{abstract}

CONCLUSIONS: Findings of the present study emphasize the benefits of exercise in Akhada Pahalwan on Pulmonary functions.

KEY WORDS: Akhada pahalwan, Exercise, Pulmonary Functions

INTRODUCTION: It is well known that exercise has a significant effect on respiratory functions $[1,2,3,4]$. Exercise increases flow of blood to various organs thereby delivering more nutrients thus improving their functioning. The effect of exercise on these organs when they are put to endurance tests has been a subject of discussion in the past. Irrefutable evidence now exists to show that regular physical activity slows the rate of decline of most of the physiological parameters that we associate with health and fitness - viz muscle strength, aerobic capacity, reaction time and joint flexibility [5]. Previous studies in this field have shown that sports persons have higher values of lung volumes in comparison to their control counterparts who are not engaged in any kind of regular physical exercises [6, 7].However, the lung functions of traditional Indian Akhada Pahalwan have not been studied so far.

AIMS AND OBJECTIVES: The aim of the present study was to investigate and report pulmonary functions of traditional Indian Akhada Pahalwan and compare these values with the pulmonary functions of young healthy adults of same age group not routinely engaged in any specific exercise.

MATERIALS AND METHODS: The present study was conducted on sixty seven male volunteers divided into two groups. 
Study group: Young male adults (18-30 years) pursuing physical activity regularly in the Akhada for at least two years (Akhada Pahalwan, $n=37$ ).

Control group: Healthy male medical students, not routinely engaged in any specific exercise acted as age and sex matched controls $(n=30)$.

Akhada pahalwan perform traditional exercises which are Isometric exercises and Isotonic (Dynamic) exercises. In isometric exercises, we increase the static strength of the muscles without affecting the endurance significantly [8,9]. This is performed in practising wrestling in the ring with a fellow pahalwan. In isotonic (Dynamic) exercises, the tension remains unchanged and the muscle's length changes, i.e. primarily increases the endurance power without affecting the static strength $[10,11,12]$. For example, most of the exercises including traditional Indian instruments and techniques are used to perform, most common are oil massage, push-up and sit up, digging the clay in the ring. Instruments used are wooden "Mugdar" (or Indian style dumbbell), which are broader at the distant end and with a handle at the other end, rope climbing and Malkhamb which is a wooden pillar about 8 feet in length tapering towards the top and oil is rubbed over it. A pahalwan using co-ordination of hands and feet, climbs over it reaches its top and balances over its tip that gives him lot of strength and coordination. Pahalwan also uses single bar, double bar for different exercises.

Their exercises can be classified as Aerobic and Anaerobic exercises. Aerobic

Exercises consist of wrestling, oil massage, climbing on rope. Anaerobic exercises include rest of the exercises like moving around mugdar, use of dumbbell, weight lifting.

The study was approved by the ethical committee of the institution and a written informed consent was taken from all the individuals of study and control group in accordance with the protocol.

Lung function parameters (Forced Vital capacity, FVC; Tidal volume, TV; Inspiratory vital capacity, IVC; Inspiratory reserve volume, IRV; Expiratory reserve volume, ERV; forced expiratory volume in first second, FEV1; Peak Expiratory flow rate, PEF; Maximum Expiratory Flow rate, MEF) were recorded on Spirometer. An interview schedule was used for all subjects in the study to obtain information related to age, socioeconomic status, and relevant personal and family history. Kuppuswamy's Socioeconomic Status Scale including criteria like education, occupation and family income was used and accordingly individuals belonging to middle class family on the basis of this scale were included. Personal history included diet, addiction if any to smoking, alcoholism or others. Exercise history included regularity in Akhada for at least past two years and duration of exercise performed each day in hours. Before the test every subject was examined thoroughly with special emphasis on respiratory system and those having any kind of respiratory problem e.g. bronchitis, bronchial asthma, tuberculosis and addiction if any to smoking, alcoholism or others were excluded from this study.

Height and weight were measured while the subject was standing erect on a plain platform without shoes. Every subject was wearing routine outfit while recording the weight.

\section{EQUIPMENTS USED:}

SPIROMETER: Modern Computerized Pulmonary function test machine manufactured by Ganshorn Medizin Electronic (Gmbh) Germany. The machine has Power cube system exclusively designed to measure and display lung function parameters. Determination of the mobilized lung volumes and partial volume is possible with Power Cube Spiro. The most important parameters 
of spirometry are the inspiratory and expiratory vital capacities. The value obtained is corrected to body surface area (BSA) and body temperature and pressure saturated

with water vapor (B.T.P.S.) The software contains prediction equations both for adults and children. Measuring scale stand was used for measuring height in centimeters. Electronic weighing machine was standardized and used for measuring weight in kilograms.

STATISTICAL ANALYSIS: Done using SPSS for windows. Statistical calculation was done by unpaired student ' $t$ ' test. A $p$ value of $<0.05$ was considered significant.

RESULTS: The measured anthropometric factors are statistically non-significant between the study and control groups ( $p>0.05$, Table 1$)$. The Forced Vital capacity $(3.98 \pm 0.56 \mathrm{~L})$ and Tidal volume $(0.86 \pm 0.37 \mathrm{~L})$ in study group (akhada pahalwan) were found to be significantly increased ( $\mathrm{p}<0.05$, Table 2) as compared to in control group (FVC $3.61 \pm 0.27 \mathrm{~L}$ and TV $0.69 \pm 0.16 \mathrm{~L})$. Inspiratory vital capacity $(3.86 \pm 0.56 \mathrm{~L})$, Inspiratory reserve volume $(1.84 \pm 0.63 \mathrm{~L})$, Expiratory reserve volume $(1.33 \pm 0.56 \mathrm{~L})$ and Forced expiratory volume in first second (3.47 $\pm 0.43 \mathrm{~L} /$ second) in study group (akhada pahalwan) were greater than the control group (IVC, 3.46 $\pm 0.27 \mathrm{~L}$; IRV, 1.6 $\pm 0.33 \mathrm{~L}$; ERV, 1.32 $\pm 0.35 \mathrm{~L}$ and FEV1, FE3.31 $\pm 0.26 \mathrm{~L} /$ second), although difference was not statistically significant ( $p>0.05$, Table 2 ).

The values of FEV1 as percentage of FVC were significantly higher in control group 91.2 $\pm 5.53 \%)$ as compared to study group (86.22 $\pm 6.68 \%)(\mathrm{p}<0.05$, Table 2$)$. The Peak Expiratory flow rate $(7.60 \pm 1.67 \mathrm{~L} /$ second), Maximum Expiratory Flow rate between $25-75 \%$ of vital capacity (MEF 25-75 \% , 4.54 $\pm 0.87 \mathrm{~L} /$ second), Maximum Expiratory Flow rate at $50 \%$ of vital capacity (MEF $50 \%, 5.26 \pm 1.13 \mathrm{~L} /$ second ), Maximum Expiratory Flow rate between $75-85 \%$ of vital capacity(MEF 75-85 \%, 7.10 $\pm 1.84 \mathrm{~L} /$ second) and Maximum Expiratory Flow rate at $25 \%$ of vital capacity (MEF $25 \%, 2.46 \mathrm{~L} /$ second) were higher in control group than akhada pahalwan

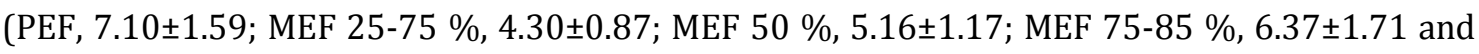
MEF $25 \%, 2.30 \pm 0.78$ ), although difference was not statistically significant ( $p>0.05$, Table 2 ).

DISCUSSION: It is a well known fact that pulmonary function parameters are influenced by race age, sex, height, weight and other unknown variables having a wide range of normal values [13, $14,15,16]$. The large metabolic demand of strenuous exercise requires an efficient oxygen transport system from the atmosphere to the active tissues. The results of the present study support the idea that physical training has a facilitative effect on ventilatory function and physically active persons have greater lung function values in comparison to sedentary persons $[17,18,19,20,21]$.

It is of interest that, akhada pahalwan had larger values of FVC, IVC, IRV, ERV and FEV1. It may be because they perform the traditional Indian exercises involving both aerobic as well as anaerobic exercises. During exercise they maintained higher muscular strength and aerobic power throughout, As the exercise progresses, anaerobic work capacity tends to be higher [22], so that the general physiological profile of the successful pahalwan is of one with high anaerobic power, high anaerobic capacity, high muscular endurance, average to above average aerobic power and normal flexibility [23]. Unfortunately, data on the isolated effects of Akhada on fitness and the type of training programme most effective for success in Akhada are scarce.

The possible explanations for their higher lungs volumes is that with repeated bouts of regular physical exercise, pulmonary minute ventilation is increased during maximal-exercise. These changes are accompanied by adaptations in ventilatory dynamics of tidal volume and 
respiratory rate. Regular training increases tidal volume both at rest and during exercise [24]. The activities performed in akhada like push-ups and sit-ups required squatting and this leads to increase in intra-abdominal pressure which in turn pushes the diaphragm up. Prolonged exercise results in increased strength and endurance of muscles of diaphragm. This results in increase in expiratory volumes. The Valsalva maneuver consists of taking a deep breath and holding it just prior to lifting a very heavy weight. When the thoracic spine region is inflated, it creates an increase in intrathoracic pressure. Forced expiration against a closed glottis will further increase intrathoracic pressure. Since a deep breath will cause the diaphragm to contract and descend into the abdominal cavity, an increase in intra-abdominal pressure ensues. Increased intrathoracic pressure is achieved rather easily because the rib cage provides a firm enclosure for the thoracic cavity. It also helps in increasing the strength of rib cage and accessory muscles of inspiration, which leads to increase in vital capacity [25].

Their activities like digging the red clay, massaging and climbing the rope increases the strength of muscles of shoulder girdle, which leads to increase in the vital capacity. Other activities like moving around of Mugdar results in increase in the strength and endurance of intercostal muscles and the accessory muscles of inspiration which include the sternocleidomastoid, the scalene, the pectoralis major and minor and the latissimusdorsi which leads to expansion of thoracic cavity, and provide increased space for lungs to expand. Regular forceful inspiration and expiration for prolonged periods during exercise leads to the strengthening of the respiratory muscles, both voluntary and involuntary. This helps the lungs to inflate and deflate maximally. This maximum inflation and deflation is an important physiological stimulus for the release of lung surfactant [26] and prostaglandin [27] into the alveolar spaces thereby increasing the lung compliance and decreasing the bronchial smooth muscle tone respectively.

When we compared FEV1 as percentage of FVC we found that physically active persons (akhada pahalwan) have less value than the control group. Similar findings have been obtained by Shapairo and Paterson [28] in their studies on U.S. naval divers during rigorous physical training programme designed to build endurance. Ekblom and Hermansen [29] have also measured lung volumes in eight top athletes belonging to the Swedish National teams and have found lower values. The reason for this is that the training of muscles of shoulder girdle leads to an increase in the vital capacity by reason of the increased strength of the accessory muscles of inspiration. The change is not accompanied by a corresponding increase in the forced expiratory volume, so the proportion of the forced vital capacity, which these subjects can expire in first second, tends to be relatively low [30].

The PEF and MEF was insignificantly ( $p>0.05$ ) higher in control group than study group. It shows that these tests are not influenced by physical training. These results support the findings of Gordon et al. [31], Newman et al. [32], Stuart and Collings [4], although, many studies show significantly higher values in physically active persons [17, 18, 19, 20, 21]. Further longitudinal studies are required to confirm these findings.

CONCLUSIONS: Akhada is a traditional Indian exercise pattern, which includes both aerobic and anaerobic exercises and almost every group of muscles are worked upon. However, there is paucity of scientific data as hardly any studies have been performed on these subjects. Within the limitation of our study we can conclude that most of the lung volumes (IVC, TV and FVC) increases following Akhada exercise in the young male adult due to strong muscles of respiration. But with the latest sophisticated and impressionable gymnasium coming up it is 
slightly difficult to convince young adults to adopt traditional Akhada exercise routine However, it is suggested that further studies need to be taken up on persons practising in akhada on various other physiological parameters in order to scientifically document the holistic influence on the body physiology.

ACKNOWLEDGEMENTS: I am very thankful to the Head of" Vijay Bahaddur Vyyayamshala", :Malhar Ashram"," for providing me subjects for my study. The contribution of the technical staff of the Department of Physiology MGM Medical College, Indore, MP, India is duly acknowledged. No funding/grant of any kind was obtained for this work.

DECLARATION OF INTEREST: The authors report no conflict of interest.

\section{REFERENCES:}

1. Ness GW, Cunningham DC, Eyon RB, Shaw DW. Cardio- Pulmonary Function in prospective competitive swimmer and their parents. J Appl Physiol 1974;37(1):27-31.

2. Newman F, Smalley BF, Thomson ML. A comparison between body size and Lung function of swimmer and normal school children. J Physiol 1961;156:9-10.

3. Rash PJ, Brant JW. Measurement of Pulmonary Function in United States Olympic free style wrestlers. Res Quart 1967;28:279-87.

4. Stuart DG, Collins WD. Comparison of vital capacity and maximum breathing capacity of athletes and non-athletes. J Appl Physiol 1959;14(4):507-9.

5. Ward J. Exercise and the older person. Austfam Physician 1994;234(4): 642-5.

6. Mehrotra PK, Varma NS, Tiwari S, Kumar P. Pulmonary Functions in Indian Sportsman playing different sports. Ind J Physiol and Pharmac 1998;42(3):412-6.

7. Mehrotra PK, Verma NS, Yadav RK, Tewari S, Shukla N. Study of Pulmonary Functions in swimmers of Lucknow City. Ind J Physiol and Pharmac 1997;41(1): 83-6.

8. Hansen JW. The training effect of repeated isometric muscle contractions. Intern $\mathrm{Z}$ Angew Physiol 1961;18:474.

9. Rasch, PJ, Morehouse LE. Effect of static and dynamic exercise on muscular strength and hypertrophy. J Appl Physiol 1941;133:161.

10. Ekblom B, Astrand PO, Saltin B, Stenberg J, Wallstom B. Effects of training on circulatory response to exercise. J Appl Physiol 1968;24:518.

11. Ekblom B. Effect of physical training on oxygen transport system in man. Acta Physiol Scand 1969;Suppl :328.

12. Saltin, B, Bloomqvist B, Mitchell JH, Johnson RL, Wieldenthal K, Chapman CB. Response to sub maximal and maximal exercise after bed rest and training. Circulation 1968;38(suppl-7).

13. Cotes JE, Dabbs JM, Hall AM, Lakhera SC, Saunders MJ, Malhotra MS. Lung function of healthy young men in India: contributory roles of genetic and environmental factors. Proc R Soc Lond 1975;B191:413-25.

14. Das SK, Ray A. Predicted form of forced vital capacity in school boys. Ind J Physiol Allied Sci 1989;43: 88-92.

15. Kamat SR, Sarma SB, Raju VRK. Indian norms for pulmonary functional observed values, predictive equations and inter correlations. J Assoc Physicians Ind 1977;25:531-40. 
16. Miller GJ, Saunders MJ, Gilson RJC, Ashcroft MT. Lung function of healthy boys and girls in Jamaica in relation to ethnic composition, test exercise performance and habitual Physical activity. Thorax 1977;32:486-96.

17. 17. Andrew GM, Becklake MP, Guleria JS, Bates DV. Heart and lung functions in swimmers and non-athletes during growth. J applied Physiol 1972;32:245-51.

18. Holmer I, Stein EM, Saltin B, Astrand PO. Hemodynamic and respiratory responses compared in swimming and running. J Appl Physiol 1974;37(1): 49-54.

19. Kaufmann DA, Swenson EW, Fencl J, Lucas A. Pulmonary function of marathon runners. Med Sci sports 1974;6:114-7.

20. Leith DE, Bradley M. Ventilaory muscle strength and endurance training. J App Physiol 1976;41:508-16.

21. Sinning W, Adrian MJ. Cardio respiratory changes in college women due to season of competitive basketball. J Appl Physiol 1968;25:720-24.

22. Utter AC, O'Bryant HS, Haff GG, Trone GA Physiological profile of an elite freestyle wrestler preparing for competition: a case study. J Strength Cond Res 2002;16(2):30815.

23. Horswill CA. Applied physiology of amateur wrestling. Sports Med 1992;14(2): 114-43.

24. Brow Dale D. Pulmonary response to exercise and Training. In: Garret WE, Kirkedall DT (ed) Exercise and sports science. Lippincot Williams and Wilkins A Walter Kluver Company, Philadelphia USA, 2000: 117-34.

25. Camilla ES, Rafel F, Lander JE, Garhammer J. Biomechanics of Power lifting and Weight lifting Exercise. In: Garret WE, Kirkedall DT (ed) Exercise and sports science. Lippincot Williams and Wilkins A Walter Kluver Company, Philadelphia USA, 2000:585-615

26. Hildebran JN, Geork J, Clements JA. Surfactant release in exercised rat lung stimulated by air inflation. J Appl Physiol 1981;51: 905-10.

27. Smith AP. Prostaglandins and the respiratory system. In: Karim SMM (ed) Advances in Prostaglandin Research, Physiological, Pharmacological and Pathological Aspects. Medical and Technical Publications, Lancaster, 1976: 83-102.

28. Shapairo W, Paterson JL. Effects of smoking and athletic conditioning on ventilator mechanisms including observation on the reliability of forced expirogram. Amer Rev Resp Dis 1962;85:191-9.

29. Ekblom B and Hearmansen L. Cardiac output in athletes. J Appl Physiol 1968;25: 619-25.

30. Cotes JE. Lung Function At Different Stages In Life, Including Normal Values. In: Lung Function Assessment and Application in Medicine, 2nd edn. Black well scientific Publication Oxford and Edinburgh, Great Britain, 1968: 345-91.

31. Gordon B, Levine SA, Wilmares A. Observation on a group of marathon runners. Arch Int Med 1924;33:425.

32. Newman F, Smalley BF, Thomson ML. Effect of exercise, body and lung size on codiffusion in athletes and non-athletes. J Appl Physiol 1962;17: 649-55. 
Table 1. COMPARISON OF ANTHROPOMETRIC FACTORS

\begin{tabular}{|l|l|l|l|l|}
\hline $\begin{array}{l}\text { Anthropometric } \\
\text { factors }\end{array}$ & $\begin{array}{l}\text { Study group } \\
\mathbf{( n = 3 7 )} \\
\text { Mean } \pm \text { S.D }\end{array}$ & $\begin{array}{l}\text { Control group } \\
\mathbf{( n = 3 0 )} \\
\text { Mean } \pm \text { S.D }\end{array}$ & p Value & RESULT \\
\hline Age (years) & $20.77 \pm 2.70$ & $21.4 \pm 3.20$ & $>0.05$ & $\begin{array}{l}\text { Non- } \\
\text { significant }\end{array}$ \\
\hline Height (cms) & $172.56 \pm 7.19$ & $169.9 \pm 6.09$ & $>0.05$ & $\begin{array}{l}\text { Non- } \\
\text { significant }\end{array}$ \\
\hline BSA (m $\left.{ }^{2}\right)$ & $1.83 \pm 0.14$ & $1.68 \pm 0.13$ & $>0.05$ & $\begin{array}{l}\text { Non- } \\
\text { significant }\end{array}$ \\
\hline Weight $(\mathrm{kg})$ & $70.25 \pm 9.84$ & $59.73 \pm 8.73$ & $>0.05$ & $\begin{array}{l}\text { Non- } \\
\text { significant }\end{array}$ \\
\hline
\end{tabular}

Abbreviations: Body Surface Area, BSA

Table 2.COMPARISON OF LUNG FUNCTION PARAMETERS IN STUDY AND CONTROL GROUP

\begin{tabular}{|l|l|l|l|l|}
\hline Lung function parameters & $\begin{array}{c}\text { Study group } \\
(\mathbf{n}=\mathbf{3 7}) \\
\text { Mean } \pm \text { S.D }\end{array}$ & $\begin{array}{c}\text { Control group } \\
\mathbf{( n = 3 0 )} \\
\text { Mean } \pm \text { S.D }\end{array}$ & p Value & Results \\
\hline $\begin{array}{l}\text { Inspiratory vital } \\
\text { capacity (litres) }\end{array}$ & $3.86 \pm 0.56$ & $3.46 \pm 0.27$ & $<0.05$ & Significant \\
\hline $\begin{array}{l}\text { Inspiratory reserve } \\
\text { volume (litres) }\end{array}$ & $1.84 \pm 0.63$ & $1.6 \pm 0.33$ & $>0.05$ & $\begin{array}{l}\text { Non- } \\
\text { significant }\end{array}$ \\
\hline $\begin{array}{l}\text { Expiratory reserve } \\
\text { volume (litres) }\end{array}$ & $1.33 \pm 0.56$ & $1.32 \pm 0.35$ & $>0.05$ & $\begin{array}{l}\text { Non- } \\
\text { significant }\end{array}$ \\
\hline Tidal volume (litres) & $0.86 \pm 0.37$ & $0.69 \pm 0.16$ & $<0.05$ & Significant \\
\hline FVC (litres) & $3.98 \pm 0.58$ & $3.61 \pm 0.27$ & $<0.05$ & Significant \\
\hline FEV (litres) & $3.47 \pm 0.43$ & $3.31 \pm 0.26$ & $>0.05$ & $\begin{array}{l}\text { Non- } \\
\text { significant }\end{array}$ \\
\hline FEV1/FVC \% & $86.22 \pm 6.68$ & $91.2 \pm 5.53$ & $<0.05$ & Significant \\
\hline MEF 25-75 \% & $4.30 \pm 0.87$ & $4.54 \pm 0.87$ & $>0.05$ & $\begin{array}{l}\text { Non- } \\
\text { significant }\end{array}$ \\
\hline MEF 25 \% & $2.30 \pm 0.78$ & $2.46 \pm 0.60$ & $>0.05$ & $\begin{array}{l}\text { Non- } \\
\text { significant }\end{array}$ \\
\hline MEF 50 \% & $5.16 \pm 1.17$ & $5.26 \pm 1.13$ & $>0.05$ & $\begin{array}{l}\text { Non- } \\
\text { significant }\end{array}$ \\
\hline MEF 75-85 \% & $6.37 \pm 1.71$ & $7.10 \pm 1.84$ & $>0.05$ & $\begin{array}{l}\text { Non- } \\
\text { significant }\end{array}$ \\
\hline PEF & $7.10 \pm 1.59$ & $7.60 \pm 1.67$ & $>0.05$ & $\begin{array}{l}\text { Non- } \\
\text { significant }\end{array}$ \\
\hline
\end{tabular}

